\title{
Review of WADA Prohibited Substances: Limited Evidence for Performance-Enhancing Effects
}

\author{
Jules A. A. C. Heuberger ${ }^{1}$ (D) Adam F. Cohen ${ }^{1,2}$
}

Published online: 8 November 2018

(c) The Author(s) 2018

\begin{abstract}
The World Anti-Doping Agency is responsible for maintaining a Prohibited List that describes the use of substances and methods that are prohibited for athletes. The list currently contains 23 substance classes, and an important reason for the existence of this list is to prevent unfair competition due to pharmacologically enhanced performance. The aim of this review was to give an overview of the available evidence for performance enhancement of these substance classes. We searched the scientific literature through PubMed for studies and reviews evaluating the effects of substance classes on performance. Findings from double-blind, randomized controlled trials were considered as evidence for (the absence of) effects if they were performed in trained subjects measuring relevant performance outcomes. Only 5 of 23 substance classes show evidence of having the ability to enhance actual sports performance, i.e. anabolic agents, $\beta 2$-agonists, stimulants, glucocorticoids and $\beta$-blockers. One additional class, growth hormone, has similar evidence but only in untrained subjects. The observed effects all relate to strength or sprint performance (and accuracy for $\beta$-blockers); there are no studies showing positive effects on reliable markers of endurance performance. For 11 classes, no well-designed studies are available, and, for the remaining six classes, there is evidence of an absence of a positive effect. In conclusion, for the majority of substance classes, no convincing evidence for performance enhancement is available, while, for the remaining classes, the evidence is based on a total of only 266 subjects from 11 studies.
\end{abstract}

\section{Key Points}

This review shows that only 5 of 23 substance classes on the World Anti-Doping Agency Prohibited List show robust evidence of having the ability to enhance actual sports performance in athletes.

A total of 11 studies including 266 subjects form all the available level 1 evidence for positive pharmacological effects on strength and sprint performance; there are no studies showing benefit on endurance performance.

Jules A. A. C. Heuberger

jheuberger@chdr.nl

1 Centre for Human Drug Research, Zernikedreef 8, 2333 CL Leiden, The Netherlands

2 Department of Internal Medicine, Leiden University Medical Centre, Leiden, The Netherlands

\section{Introduction}

The mission of the World Anti-Doping Agency (WADA) is to lead a collaborative worldwide movement for doping-free sport, and its activities focus on the responsibilities given by the World Anti-Doping Code [1]. One of these responsibilities is to publish an annual Prohibited List, which identifies the substances and methods prohibited in- and out-of-competition, and in particular sports [2]. This list is compiled by the List Expert Group and Health, Medical and Research Committee of the WADA, in consultation with scientific, medical and anti-doping experts, using criteria described in the World Anti-Doping Code. This describes that a substance or method shall be considered to be placed on the Prohibited List if the substance or method meets any two of the following three criteria [1].

1. Medical or other scientific evidence, pharmacological effect or experience that the substance or method, alone or in combination with other substances or methods, has the potential to enhance, or enhances, sport performance. 
2. Medical or other scientific evidence, pharmacological effect or experience that the use of the substance or method represents an actual or potential health risk to the athlete.

3. WADA's determination that the use of the substance or method violates the spirit of sport, described in the introduction to the World Anti-Doping Code.

The third criterion is clearly most subjective and is more a fundamental and philosophical question than a scientific one [3]. However, the remaining two criteria do mention the availability of scientific evidence, indicating that the decision for placing substances and methods on the Prohibited List could be evidence-based. So how strong is this evidence for the listed substances? In this review, we specifically focus on the evidence for performance enhancement, although there could be other reasons athletes use prohibited substances, including masking or diminishing the side effects of other prohibited substances. Several reviews are available focusing on the performance effects of different categories on the Prohibited List [4-7]; however, the current review aims to provide a comprehensive and up-to-date overview of the evidence for performance enhancement of all categories of substances in- and out-of-competition on the 2018 Prohibited List, applying standards considered appropriate in clinical therapeutics.

\section{Methodological Considerations}

The 2018 Prohibited List was used as framework for this review [2]. We searched the scientific literature for studies and reviews evaluating the clinical effects of the different substances and categories of substances on performance using PubMed as the search engine. Scientific articles with no date restriction and with combinations of the following keywords were evaluated for their relevance by title and abstract: 'athletes', 'performance', 'sport', 'doping' and 'trained', in combination with a specific prohibited compound or category (e.g. 'terbutaline' or ' $\beta 2$-agonist'). Reference lists of identified publications were searched for additional relevant publications. Performance was interpreted according to the broadest sports-related definition, including strength (power) and endurance. Although the criterion in the WADA Code states that evidence for the potential to enhance performance is sufficient to place a substance on the Prohibited List, in this review clinical pharmacological evidence for actual performance enhancement was considered essential to determine that a substance or category of substances has a positive effect on performance. In other words, similar to any other therapeutic review, to make an evidence-based conclusion that there are performanceenhancing effects, the level of evidence should preferably be high (level 1), meaning that evidence should come from double-blind, randomized controlled trials (or meta-analysis based on randomized controlled trials) [8]. This was also taken into account when evaluating the search results, although there will inevitably be cases where information has to be inferred from other, less-reliable evidence. In addition, ideally these trials should measure relevant performance outcomes, and therefore we defined which outcomes should be considered most relevant. In this review, we apply the same standard as for clinical trials, where proven effects on clinical outcome are accepted as most reliable, and effects on surrogate markers that have a proven link to that clinical outcome are accepted, as, for example, described by the US FDA [9]. When translated to sport performance, the most relevant outcome measure is the 'actual' performance of the sport itself, such as, for example, muscle strength for weight lifting, or running time for distance running. However, surrogate markers that describe an important aspect of the performance might be acceptable, but conclusions based on such markers can only be reliable if there is a proven high correlation with the actual performance. For endurance performance, for example, although maximal oxygen consumption $\left(V \mathrm{O}_{2 \max }\right)$ is often used and has been shown to be a prerequisite for performance $[10,11]$, its predictive value for endurance performance within a group of athletes is very limited $[12,13]$. Moreover, it seems that successful endurance athletes reach a plateau in $\mathrm{VO}_{2 \max }$ despite continuing to improve performance [14-16], thereby questioning whether increasing $V_{2}$ max by any means would have an impact on performance, at least in highly trained subjects. Finally, there has been critique on the use of the maximal exercise test that generates the $V \mathrm{O}_{2 \max }$ marker, to accurately evaluate athletic potential in general as it does not resemble normal exercise [17]. It is therefore unclear whether a pharmacological effect on $V \mathrm{O}_{2 \max }$ (or other maximal exercise test markers) translates into an effect on performance per se, making it a marker with insufficient predictive value. Another test that is not very reliable in measuring effects on actual performance is the time-to-exhaustion test. Such a test has been shown to have low reproducibility, especially compared with time trials that continue for a predetermined amount of time or work $[18,19]$. Moreover, there is no clear evidence of their correlation with actual performance, except for the absence of a correlation with Ironman performance in one study [20]. This is possibly because sports disciplines do not rely on time-to-exhaustion principles, but rather on pacing to a finish line or time. In summary, there currently are no widely recognised laboratory markers for (aerobic) endurance performance, leaving tests for actual endurance performance (e.g. a time trial) as the most reliable available measure. On the other hand, markers for sprint performance, for example as measured by a Wingate test, do resemble actual performance, such as sprinting in cycling, and this 
surrogate marker has also been shown to correlate with other performance types [21,22], which is why we considered it to be a relevant marker.

Finally, the training status of study participants is a relevant factor when interpreting the outcome. The aim of preventing performance advantages through doping, as described in the WADA Code, is most (although admittedly not solely) relevant in high-level (and in particular professional) sports due to the attention, fame and commercial considerations involved in that level of sports. Clinical studies should reflect the 'target population', which in this case would be elite and professional athletes. However, because of doping/WADA regulations, it was/is very challenging, or even impossible, to conduct intervention studies of banned substances in such a population. For this reason, we considered studies in (highly) trained athletes most relevant, so that observed effects apply to this level of athletes, and that extrapolation of observed effects in this population to the performance of professional athletes was most valid. However, data in less well-trained subjects may also be of value, and was also reviewed. Determining the training level of subjects was based on commonly used markers for performance where possible. For the level of training in endurance performance, $V \mathrm{O}_{2 \max }$ and maximal power output $\left(P_{\max }\right)$ were used. Three categories were defined somewhat arbitrarily (without taking the type of maximal exercise testing protocol into consideration): untrained $\left(V \mathrm{O}_{2 \max }<55 \mathrm{ml} / \mathrm{min} / \mathrm{kg}\right.$ and/or $\left.P_{\max }<3.5 \mathrm{~W} / \mathrm{kg}\right)$; trained $\left(V \mathrm{O}_{2 \max } \geq 55\right.$ and $<65 \mathrm{ml} /$ $\mathrm{min} / \mathrm{kg}$ and $/$ or $P_{\max } \geq 3.5$ and $<5.0 \mathrm{~W} / \mathrm{kg}$ ); and highly trained $\left(V \mathrm{O}_{2 \max } \geq 65 \mathrm{ml} / \mathrm{min} / \mathrm{kg}\right.$ and $/$ or $\left.P_{\max } \geq 5.0 \mathrm{~W} / \mathrm{kg}\right)$. For strength training, it was more difficult to objectively categorize study populations as available measurements varied widely between included studies. Therefore, subjects were categorized as trained or untrained based on the description in the article of whether subjects had been actively engaged in resistance training.

\section{Findings}

\subsection{Prohibited at All Times}

\subsubsection{S0: Non-approved Substances}

Any pharmacological substance that has no current approval by any governmental regulatory health authority for human therapeutic use belongs in this category, making the category very broad. Substances in this category could be drugs under preclinical or clinical development, discontinued drugs, designer drugs, or substances approved for veterinary use only. In any case, they will be substances that (currently) lack solid evidence for (beneficial) effects in humans in general, and therefore, in practically all cases, lack evidence for enhancement of performance in particular.

\subsubsection{S1: Anabolic Agents}

Anabolic agents, or anabolic-androgenic steroids (AAS), are synthetic derivatives of testosterone that have attracted attention as doping substances due to their potential to increase protein synthesis and decrease protein breakdown (anabolic effects) and increase muscle growth (androgenic effects) by activating the androgen receptor. In 2004, a very thorough review evaluated the evidence for the effects of AAS on performance [23].

Upon inspection of the studies covered in this current review, there were various studies with a randomized, double-blind, controlled design that investigated the effects on strength. The most recent of these studies shows clear effects of AAS on different strength outcomes in strengthtrained men, alone and combined with strength training [24-26]. One of these studies showed, with an elegant design, that high-dose testosterone $(600 \mathrm{mg} /$ week $)$, both with and without strength training, significantly increased bench-press and squatting power by, on average, 10-20\% compared with the respective placebo condition [24]. Other, well-designed studies covered in the review, investigating the effects on endurance performance, or related measures such as $V \mathrm{O}_{2 \max }$, are older and more sparse. These showed no treatment-induced improvements, although they did not show an effect on strength either, indicating the sample size or dose might be too small to detect effects [27, 28]. However, since the review, an additional randomized, placebocontrolled trial has been conducted that also showed a lack of effect on endurance performance markers after 1 month of AAS in doses similar to those that showed strength effects [29]. Additionally, this study showed evidence that there is no effect of AAS treatment on recovery. In summary, highdose AAS appears to increase strength but not endurance performance. The evidence on strength effects is based on three studies including a total of 91 volunteers.

\subsubsection{S2: Peptide Hormones, Growth Factors, Related Substances and Mimetics}

\subsubsection{Erythropoietins and Agents Affecting Erythropoiesis}

These agents are aimed at increasing red blood cell volume through inducing erythropoiesis, and thereby potentially enhancing performance. Interestingly, for 'natural' increases in red blood cell volume through altitude training, the evidence for performance-enhancing effects is not fully convincing [30].

Erythropoietin-Receptor Agonists Erythropoietin-receptor agonists, such as recombinant human erythropoietins (rHuEPOs), stimulate erythropoiesis and thereby increase 
haemoglobin levels, which potentially increases oxygen carrying capacity and hence improves endurance performance. However, a systematic review of the literature by Heuberger et al. concluded that there was a lack of evidence for efficacy on endurance performance [31]. Of the 13 available reviewed studies, only 5 had a placebo-controlled and double-blind design [32-36], all showing similar effects of rHuEPOs in both trained and untrained subjects. In all studies, $V \mathrm{O}_{2 \max }$ increased by approximately $7 \%$, while $P_{\max }$, which was evaluated in two of the studies, also increased by $7 \%[33,36]$. Finally, time to exhaustion improved by $22 \%$ in untrained subjects [33] and $9.4 \%$ in trained subjects [32]. Two subsequent randomized, placebo-controlled trials also showed increases in $V \mathrm{O}_{2 \max }, P_{\max }$ and time to exhaustion of $5 \%, 6 \%$ and $58 \%$, respectively, in trained subjects [37], and an increase in $V_{2} \mathrm{O}_{2 \max }$ of $6 \%$, but no increase in time to exhaustion, in untrained subjects [38]. However, none of these studies showed whether these effects on surrogate biomarkers impacted actual performance. Because of this lack of information, a double-blind, randomized, placebocontrolled study in trained cyclists followed and showed that clinically more relevant tests, such as a time trial and uphill road race, were not affected by rHuEPO treatment [39]. Although there was again an effect of rHuEPOs on maximal exercise test variables, including $V \mathrm{O}_{2 \max }$ and $P_{\max }$ (an increase of 5 and 3\%, respectively), there was no evidence to suggest that these erythropoietin-induced effects improved actual cycling performance in trained cyclists. The absence of an effect on these measures most related to competitive (cycling) performance in athletes is insightful, but one should be cautious about extrapolating these findings to all performance types in elite athletes-not all performance aspects of endurance have been studied, and the target population has not been included. In any case, there is no evidence showing that rHuEPOs enhance time trials, climbing or other race performance in athletes.

Hypoxia-Inducible Factor Activating Agents Hypoxiainducible factor (HIF) activating agents have a direct effect on erythropoietin production by stimulating erythropoietin gene expression, therefore the same rationale for potential performance-enhancing effects applies as for direct rHuEPO administration. As shown for rHuEPOs in the section above, increases in erythropoietin, and the accompanying increases in haemoglobin, have not been shown to improve endurance performance in trained subjects. Moreover, evidence for the effects of HIF activating agents is even more sparse. Cobalt has been observed to increase erythropoiesis in anaemic patients $[40,41]$. No trials have been performed evaluating these effects on erythropoiesis or performance in healthy volunteers, let alone athletes, as can be seen in the review by Ebert and Jelkmann [42]. More recently, a study claimed to show the effects of xenon on erythropoietin production in healthy volunteers [43], but the statistics of the study have been criticized [44]. Small molecule HIFs are in clinical development but have not yet been approved for clinical use. The published clinical studies show that these compounds produce modest increases in erythropoietin in both anaemic patients and healthy volunteers $[45,46]$, however there are currently no studies evaluating effects on the performance of healthy or trained subjects.

GATA Inhibitors By inhibiting GATA, an erythropoietin gene expression inhibitor, a similar effect as for the HIF activating agents could be expected; however, there are no published clinical studies on the effects of these compoundsthe mechanism has only been proven preclinically $[47,48]$.

Transforming Growth Factor- $\beta$ Inhibitors Erythropoietin induction by transforming growth factor (TGF)- $\beta$ inhibition is a very recent development in the possible treatment of anaemia, and in particular for myelodysplastic syndromes. Luspatercept and sotatercept have been shown to increase haemoglobin levels in such patients $[49,50]$, but there is no evidence regarding any related effects on performance in healthy or trained individuals.

Innate Repair Receptor Agonists Innate repair receptor agonists are non-erythropoietic derivatives of rHuEPO that have been developed for their potential tissue-protective properties, and that to date have only been evaluated in a few clinical trials. One published placebo-controlled trial indicated carbamylated erythropoietin was safe and welltolerated [51], but no evidence of performance effects is available.

\subsubsection{Peptide Hormones and Hormone Modulators} Chorionic Gonadotrophin and Luteinizing Hormone and Their Releasing Factors Chorionic gonadotrophin (CG) and luteinizing hormone ( $\mathrm{LH})$ are hormones that bind to the same receptor (LHCG receptor), which has several functions in the reproductive system. In females, follicular maturation, ovulation and luteal function are influenced through stimulation of the receptor in the ovary, while in males the receptor is located in the testis and stimulates testosterone production. There is no indication that the effects in females can positively influence performance [52], but the increase in testosterone in males may give similar effects as those described for anabolic agents. For example, a single intramuscular injection of $6000 \mathrm{IU}$ of CG increased testosterone levels by approximately $40 \mathrm{nmol} / \mathrm{l}$ in healthy men [53] This is half the increase observed after a 10-week treatment with $600 \mathrm{mg}$ of testosterone enanthate (an anabolic steroid), which has been shown to increase bench press and squat muscle strength [24]. However, no studies have investigated the effects of GC or LH on any sports performance measures.

Corticotrophins and Their Releasing Factors Adrenocorticotropic hormone (ACTH) is involved in the hypothalamic-pituitary-adrenal axis and is released in response to 
stress, leading to increases in cortisol. Through this cortisol response, free fatty acids are released, potentially sparing glycogen, which is then assumed to benefit endurance performance. In addition, ACTH stimulates glucocorticoid secretion (see Sect. 3.2.4). However, a double-blind, placebo-controlled, crossover study in 16 trained cyclists showed that although a $1 \mathrm{mg}$ ACTH depot dose decreased the feeling of fatigue during a submaximal effort, it did not improve maximal performance in a maximal exercise test, nor did it affect recovery between two consecutive tests [54]. Similarly, 20-km time-trial performance was not affected by $0.25 \mathrm{mg}$ ACTH intramuscular injections in a double-blind, placebo-controlled, crossover study in eight (highly) trained male cyclists [55]. Perceived fatigue was not decreased by ACTH in this study. As these are the only studies performed, we conclude there is no evidence of beneficial effects of ACTH or its releasing factors on actual performance.

Growth Hormone, Its Fragments and Releasing Factors Growth hormone (GH) use in adults with GH deficiency results in reduced body fat, increased lean body mass and increased fitness and strength [56], and has therefore attracted attention as a potential performance-enhancing drug. This mechanism is mainly mediated by insulin-like growth factor (IGF)-1. A systematic review evaluated the effects on strength or endurance performance [57]. For strength, two double-blind studies were identified that showed no effects of GH on the muscle strength of different muscles compared with placebo when combined with strength training in untrained [58] and trained strength athletes [59]. Endurance performance was evaluated in two double-blind studies; multiple dosing of GH did not have an effect on $V \mathrm{O}_{2 \max }$ and $P_{\max }$ compared with placebo in trained subjects [60]. In a crossover design, a single dose of $\mathrm{GH}$ increased plasma lactate levels during submaximal cycling exercise compared with placebo in seven highly trained cyclists [61]. Such single administrations of GH therefore seem to decrease endurance performance, underlined by the fact that three of seven cyclists in this study had difficulty completing the cycling trial when treated with GH, compared with none receiving placebo treatment. Following the review, one randomized, placebo-controlled, blinded trial with 8 weeks of daily GH treatment confirmed these findings and showed no effects on strength or $V \mathrm{O}_{2 \max }$. In this study, there was however an increase in sprint performance in a $30 \mathrm{~s}$ maximal sprint test (Wingate test) of approximately $1 \mathrm{~kJ}$ (or a $3.9 \%$ relative increase in the combined male and female group, and a $5.5 \%$ relative increase for the male group only), which was slightly larger when GH was coadministered with weekly testosterone doses [62]. It should be noted that $\mathrm{GH}$ also increased the incidence of swelling, joint pain and paraesthesia in this study, indicating these gains are not without downsides and possible risks. Additionally, subjects were untrained for endurance, therefore it is difficult to know how this effect on sprint performance extrapolates to elite athletes.

\subsubsection{Growth Factors and Growth Factor Modula-} tors Blood platelets can release growth factors for example when triggered by signs of injury. These could potentially be used for treating sports injuries [63], but are also thought to provide benefit in healthy athletes. However, for most of these factors, including fibroblast, hepatocyte, mechano, platelet-derived and vascular endothelial growth factors, and thymosin- $\beta 4$, there are no studies regarding the effects on performance. The only available studies evaluated the safety or efficacy of these products in healthy volunteers and patients [64-66]. However, there is one exception: IGF-1, which is thought to possess ergogenic effects mainly through the anabolic pathway that is shared with $\mathrm{GH}$, has been investigated as an ergogenic aid. A randomized, double-blind, placebo-controlled study investigated the effects of a recombinant human IGF-1/IGF-binding protein-3 complex (rhIGF-I/rhIGFBP-3) on body composition and aerobic performance in untrained persons [67]. No effects on body composition were observed but an increase in $V \mathrm{O}_{2 \max }$ was reported for both low (30 mg/day) and high $(60 \mathrm{mg} /$ day) doses. However, the conclusion that IGF-1 therefore improves aerobic fitness should be interpreted with caution. First, changes in outcome parameters were only analysed within each group and were not compared with the placebo group, which would have been the appropriate analysis in such a study design. Second, even if the observed effect on $V \mathrm{O}_{2 \max }$ is truly caused by IGF-1, it is unclear if this has an impact on actual performance. Unfortunately, no performance parameter such as running speed on the treadmill test was reported, nor was a test performed mimicking actual sports performance. In addition to the fact that participants were untrained, this makes it impossible to interpret what these findings mean for the performance of elite athletes.

\subsubsection{S3: $\beta 2$-Agonists}

$\beta 2$-Agonists are used in the treatment of asthma as they act as bronchodilators through their relaxing effect on the smooth muscles of the lung via the $\beta 2$-adrenergic receptor. In addition, they have an effect on muscle tissue through this pathway, and both actions have been implied to possess performance-enhancing effects. Several extensive reviews have evaluated the evidence for this. In a 2011 systematic review based on a meta-analysis of randomized controlled trials, Pluim et al. [68] concluded that there are no positive effects of inhaled $\beta 2$-agonists on endurance, strength or sprint performance, and that there was insufficient evidence to draw conclusions regarding systemic $\beta 2$-agonist use. In 2015, Cairns and Borrani [69] had more systemic dosing studies at their disposal, and concluded in their review that only 
high-dose systemic $\beta 2$-agonists (at a serum concentration of approximately $0.1 \mu \mathrm{mol} / \mathrm{l}$ ) have a positive effect on muscle strength and peak sprint power. This is based on the observation, in a placebo-controlled, randomized, crossover design in highly trained and trained men, that after oral administration of 20-25 mg terbutaline, sarcoplasmic reticulum rates of $\mathrm{Ca}^{2+}$ release and uptake were increased, together with maximal voluntary isometric contraction $(+6 \%)$ and peak twitch force $(+11 \%)$ [70]. No effects on time to exhaustion were observed. High-dose $(15 \mathrm{mg})$ inhaled terbutaline reached similar serum concentrations (approximately $0.1 \mu \mathrm{mol} / \mathrm{l}$ ) in another double-blind, randomized, crossover trial, and increased quadriceps muscle strength by $8.4 \%$. In addition, Wingate peak and mean power increased by $2.2 \%$ and $3.3 \%$, respectively, and Wingate total work increased by $3 \%$ compared with placebo in trained males, but timetrial performance was not affected [71]. A double-blind, randomized, placebo-controlled study in highly trained athletes published after the review by Cairns and Borrani [69] showed that single and 2-week dosing of $8 \mathrm{mg}$ salbutamol had no effect on body mass, $V \mathrm{O}_{2 \max }$, incremental peak power output, time to exhaustion, maximal voluntary isometric contraction or isometric endurance. However, there was a significant increase in Wingate peak power of $4 \%$ and $6 \%$ for single and multiple dosing, respectively, similar to the inhaled terbutaline study [72]. The statistical analysis in this study did not include a comparison to the placebo treatment, but because no significant effect was observed in the placebo group, the increase in the salbutamol group seemed to be a true effect. In all three studies, subjects experienced mild side effects, namely tremor and tachycardia. Only one additional study showed the effects of inhaled administered $\beta 2$-agonists. In this case, the effect was only seen in one very specific task, of which the clinical relevance is questionable, namely quadriceps endurance in highly trained endurance athletes [73], and therefore the vast majority of evidence shows no ergogenic effects of inhaled $\beta 2$-agonists. Overall, these findings indicate that only high $\beta 2$-agonist concentrations, which are mainly achieved by systemic administration, can improve performance, but only in strength and very short disciplines requiring high-power development, as represented by the Wingate test, and at the cost of tremor and tachycardia. This evidence is based on three studies with a total of 39 volunteers.

\subsubsection{S4: Hormone and Metabolic Modulators}

3.1.5.1 Aromatase Inhibitors Aromatase inhibitors lead to reduced enzyme activity for the conversion of androgens to oestrogens. This in turn leads to lowered oestrogen levels, and thereby, via inhibition of negative feedback on the hypothalamus, to higher testosterone levels. This increase has been shown to be approximately $15 \mathrm{nmol} / 1$ in healthy males, for exemestane [74]. As for CG and LH, there are no trials investigating the effects of these aromatase inhibitors on performance, and the only indication of potential effects is an increase in testosterone, which is approximately $25 \%$ that observed after AAS treatment, leading to increased muscle strength [24]. Evidence is therefore similarly weak as described for GC and $\mathrm{LH}$.

3.1.5.2 Selective Estrogen Receptor Modulators The evidence basis for selective estrogen receptor modulators (SERMs) is similar to that for aromatase inhibitors. SERMs, such as tamoxifen and raloxifen, are clinically used for their estrogenic and anti-estrogenic effects in different tissues. This induces increases in pituitary gonadotrophin secretion and, consequently, increases in testosterone levels in men, seemingly somewhat smaller than for aromatase inhibitors [75]. There are no studies investigating the effects of SERMs on performance.

3.1.5.3 Other Anti-estrogenic Substances The examples mentioned in the 2018 Prohibited List in this category, clomiphene and cyclofenil, are older SERMs (although perhaps less selective than, for example, tamoxifen). As effects are similar to compounds described in the previous section, and there are no studies on performance enhancement [76, 77], the conclusion about the evidence for performance effects is the same-no evidence is available. Another substance in this category, fulvestrant, is a selective estrogen receptor degrader with no effects that could clearly enhance performance, and no evidence that it does so.

3.1.5.4 Agents Modifying Myostatin Function(s) Myostatin is a negative regulator of muscle growth, therefore lowering its levels or inhibition of its action could potentially increase muscle size and improve performance. Although muscle growth is observed in some preclinical studies, it is questionable if this also results in increased strength, as reviewed by Fedoruk and Rupert [78]. In addition, there are currently no approved drugs (developed for diseases with muscle weakness or wasting) in this class yet [79], therefore there is presently no evidence of the effects on performance in athletes.

3.1.5.5 Metabolic Modulators There are several substance types in the metabolic modulators category. Peroxisome proliferator-activated receptor (PPAR)- $\delta$ agonists and AMPactivated protein kinase (AMPK) activators might enhance performance through their effects on energy expenditure and substrate utilization. In mice, a PPAR- $\delta$ agonist, as well as an AMPK agonist [i.e. 5-aminoimidazole-4-carboxamide ribonucleotide (AICAR)], increased running endurance [80]. However, there are currently no approved PPAR- $\delta$ agonists [81], and neither is there evidence for performance enhance- 
ment in humans. Similarly, specific AMPK activators are not approved (such as AICAR), although there are approved drugs that have an AMPK activating effect, e.g. metformin, which is not prohibited. However, clinical studies evaluating the effects on performance in healthy subjects are sparse, as reviewed by Niederberger et al. [82]. That review cites two studies evaluating metformin effects in healthy volunteers, one of which was a multiple-dose, double-blind, placebocontrolled crossover trial [83]. The blinding of this study was described as not being optimal (due to taste and gastrointestinal side effects), randomization is not described, and there was no baseline measurement for each treatment, making the conclusions less robust. Nevertheless, no positive effect on performance markers was observed. Moreover, a small but significant decrease in $V \mathrm{O}_{2 \max }$ and time to exhaustion in the maximal test was found in the metformin treatment group. The second study was a randomized, double-blind, placebo-controlled, single-dose, crossover study that showed no difference between treatments, although this study also did not include a baseline measurement [84]. In both studies, participants were untrained.

With regard to insulin, Kuipers and van Dugteren indicated that based on several observations, this drug is not expected to have a physiologically significant effect on muscle growth, even in combination with glucose and/or amino acids [85]. However, no studies have been published assessing the effects of insulin on performance.

Finally, inhibitors of fatty acid oxidation belong to this category. Meldonium is classified as a partial inhibitor of fatty acid oxidation, but, in a recent editorial, Greenblatt and Greenblatt concluded that no studies have evaluated the performance-enhancing properties of meldonium in trained subjects [86]. Another inhibitor of free fatty acid oxidation, trimetazidine, was reported to improve maximal walking distance in patients with peripheral arterial disease [87], but there is no evidence of such an effect on exercise performance in healthy or trained individuals.

\subsubsection{S5: Diuretics and Masking Agents}

The category of diuretics and masking agents is not necessarily included in the Prohibited List for their potential to enhance performance. Masking agents are supposed to interfere with analytical testing of markers or other substances on the Prohibited List. Diuretics increase urine production and by this effect are thought to dilute, and therefore interfere with the detection of, banned substances in urine. This increased water excretion caused by diuretics might also improve performance as it can quickly reduce weight, which might give a competitive advantage. In sports with weight classes, for example, this effect could place athletes in a lighter category, and, in speed or endurance sports, lighter athletes might have an advantage. Cadwallander et al. [88] reviewed the effects of diuretics, but it should be noted that some of the studies were not placebocontrolled, and only used a control condition. Although it could be argued that the diuretic effect would have deblinding effects anyway, the results should be interpreted with caution. Caldwell et al. [89] showed that two doses of approximately $60 \mathrm{mg}$ of furosemide decreased work load during a maximal exercise test and decreased $V \mathrm{O}_{2 \max }$ compared with baseline measurements, but not compared with controls, in untrained subjects. Armstrong et al. [90] found that trained runners had an impaired running time in 1500,5000 and $10,000 \mathrm{~m}$ races after $40 \mathrm{mg}$ of furosemide, a difference that was significant at the two longest distances versus controls. A third study did not find an effect of a $1000 \mathrm{mg}$ infusion of acetazolamide on 30 s peak or average cycling power, although it did seem to decrease peak $V \mathrm{O}_{2}$ uptake during this test [91]. Another study evaluated the effects of a single dose of $500 \mathrm{mg}$ acetazolamide in a quasi-randomized, double-blind, placebo-controlled, crossover study and found that there was no effect on $V \mathrm{O}_{2 \max }$, but time to exhaustion was reduced by $29 \%$ in a continuous exercise to exhaustion [92]. Finally, a double-blind, placebocontrolled, crossover study in untrained subjects investigated the effects of four doses of $250 \mathrm{mg}$ acetazolamide every $8 \mathrm{~h}$ and found a decrease in $V \mathrm{O}_{2 \max }$ and $P_{\max }$ [93]. An additional study that was not covered in the review by Cadwallander et al. [88] showed that in a randomized, double-blind, placebo-controlled, crossover study, $250 \mathrm{mg}$ acetazolamide three times daily for 2 days did not significantly affect knee extension maximum voluntary contraction at the beginning of the test or at exhaustion in untrained subjects [94], but did decrease endurance performance. Overall, not all study designs were sufficiently robust and most included untrained subjects, therefore definite conclusions cannot be made regarding the performance-enhancing properties of diuretics. Nonetheless, given the available studies, if anything the evidence indicates that athletic performance is negatively affected by diuretics.

\subsubsection{M1-3: Prohibited Methods}

There are several non-pharmacological interventions that are prohibited at all times, termed prohibited methods. These are manipulation of blood and blood components (e.g. blood transfusion), chemical and physical manipulation (e.g. tampering with a sample or intravenous infusions of fluid) and gene doping. As this review focuses on pharmacological interventions, evidence for the effects on performance of these categories is not discussed here.

\subsection{Prohibited In-Competition}

\subsubsection{S6: Stimulants}

Stimulants are thought to potentially improve performance via the effects on neurotransmitter levels in the brain, 
predominantly dopamine and norepinephrine. Research into the effects of stimulants on performance has mainly focused on a few drug classes. Amphetamines such as amphetamine sulfate [95] showed positive effects on muscle strength (knee extension strength $+23 \%)$, acceleration $(+4 \%)$ and time to exhaustion $(+5 \%)$ in untrained subjects. Similarly, methylphenidate [96] improved time to exhaustion (+29\%) in highly trained subjects. $V \mathrm{O}_{2 \max }$ was not affected in either study and endurance performance (such as a time trial) was not investigated in these studies. Of note, the former study used no baseline correction (i.e. amphetamine performance was directly compared with placebo performance in the randomized, crossover design) and, for the latter study, it is unclear whether it was (double-)blinded, which may both make the results less robust. Another study with a higher dose of methylphenidate showed no effect on time-trial performance in normal temperature, but there was an improvement of $15 \%$ average power output compared with placebo in the heat $\left(30^{\circ}\right)$ in trained subjects [97]. Levomethamphetamine was investigated for its effect on time-trial performance in young participants and showed no change [98].

Ephedrine, pseudoephedrine and phenylpropanolamine have a similar mechanism of action to amphetamines. Two studies investigating the effects of ephedrine showed positive effects. One study found an effect on peak Wingate sprint power $(+0.6 \%)$, but not on time to exhaustion [99], in untrained subjects, and another study found an improvement in a type of time-to-exhaustion test in trained strength athletes, namely leg and bench press repetitions $(+30 \%$ and $+8 \%$, respectively) [100]. One positive study for pseudoephedrine used a dose of $180 \mathrm{mg}$, which increased knee extension strength by $9 \%$ and peak Wingate sprint performance by $3 \%$, but not bench press power, in strengthtrained subjects [101]. Later publications also showed that low doses of pseudoephedrine used clinically did not affect $5000 \mathrm{~m}$ run time in highly trained runners [102], or peak power or total work during a Wingate test in trained subjects [103]; only high doses improved performance, with $1500 \mathrm{~m}$ run time decreasing by $2 \%$ in highly trained runners [104]. The authors of this latter study therefore concluded that high pseudoephedrine doses are needed for performance effects.

For cocaine, another well-known stimulant that is on the Prohibited List, there are no well-designed studies evaluating its effects on performance.

Overall, studies on the effects of these stimulants show varying results, making it unclear whether they improve performance, as was concluded in a review published by Clarkson and Thompson in 1997 [6]. In certain conditions and performance tests, they may modestly improve performance if administered in sufficiently high doses, but there is insufficient conclusive evidence to determine how they affect most actual sports performance types. The available evidence consists of the results of two studies involving a total of 29 volunteers.

\subsubsection{S7: Narcotics}

The narcotics category consists of strong analgesics, all belonging to the opioids class. Surprisingly, although not all opioids are currently banned (e.g. tramadol is allowed), substances such as morphine and its analogs, and fentanyl and its derivatives, are. Although analgesic effects might enhance performance, common side effects of opioids, including nausea, sedation and respiratory depression, would equally argue against any beneficial effects. One study showed that an intrathecal injection of fentanyl did not impact average power output during a $5-\mathrm{km}$ cycling time trial in trained cyclists [105]; however, power output during the first half of the time trial was increased, and then decreased during the second half, compared with placebo. The authors attributed this to attenuated afferent feedback from exercising muscles, which is then followed by excessive development of fatigue, and overall deterioration of the ability to 'dose' their effort. Besides this report, there are no convincing clinical studies on the effects of narcotics on sports performance, resulting in a lack of evidence for either positive or negative effects on performance, as was also concluded by the authors of a recent review [106].

\subsubsection{S8: Cannabinoids}

Cannabinoids are known to affect perceptual function, and in a review of (non-sport) performance, Huestis [107] concluded that this leads to decreased ability to concentrate and maintain attention. In addition, this review concluded that cannabinoids impair information processing and reaction time, all of which would probably negatively affect sports performance, as concluded in a more recent review [108]. Around the same time, Huestis et al. [109] argued that although there are indications that in some settings cannabis has a detrimental effect on performance, in other settings known effects of cannabis might be beneficial. Examples include sports where vision or muscle relaxation are important, or when anxiety or fear impair the potential of the athlete. However, very few scientific data are available on the effects of cannabinoids on sports performance itself, a conclusion that was also reached in two recent reviews $[110,111]$. A double-blind, randomized, placebo-controlled, crossover study has been conducted showing tetrahydrocannabinol (THC) had no effect on handgrip strength and decreased performance in a specific type of submaximal bicycle test compared with placebo in healthy untrained males [112]. This shows there is no evidence for performance enhancement of cannabinoids. 


\subsubsection{S9: Glucocorticoids}

Glucocorticoids act on metabolism and the immune system, and, through that mechanism, potentially affect performance. For this reason, systemic doses are prohibited in competition. A recent review showed there are varying results of glucocorticoid treatment in performance tests [113]. The two available controlled studies evaluating maximal exercise test variables failed to show effects on $V \mathrm{O}_{2 \max }$ and ventilator threshold of 5 days of dexamethasone in untrained subjects [114], and on $P_{\max }$ of 4 weeks of budesonide treatment in trained subjects [115]. The effects on short, intense exercise were evaluated in three studies. In untrained men, one-legged knee-extensor exercise time to exhaustion was not affected by 5 days of dexamethasone [116]. In contrast, using a similar dosing scheme, another study found an increase in one-legged knee-extensor exercise time to exhaustion of $29 \%$, and running distance in a certain type of maximal exercise test, namely 20 -m shuttle-run test, of $19 \%$ [117]. Sprint performance over $30 \mathrm{~m}$ was not affected in this study. The authors of the latter study postulated a lack of statistical power in the former study was the cause of this apparent discrepancy in outcomes between the two studies. A third study evaluated the effects of a single dose of prednisone on one-legged hopping, and found an $11 \%$ improvement in maximal force of the first bout, but not on subsequent bouts or time to exhaustion in any of the bouts [118]. However, it should be noted that no baseline measurement was performed on the study day and therefore the effects of interoccasion variability cannot be excluded. Similar to these short, intense exercise studies, results from studies investigating types of cycling performance are equivocal. A single dose of $20 \mathrm{mg}$ prednisolone did not affect cycling time to exhaustion in trained males, alone or in combination with $4 \mathrm{mg}$ salbutamol [119], a finding that was confirmed in a similar study [120]. However, a multiple dose of $60 \mathrm{mg}$ prednisolone daily for seven days did increase cycling time to exhaustion in trained males by $28 \mathrm{~min}(62 \%)$, although this performance was not controlled with a baseline measurement [121]. An almost identical study that did include a baseline measurement showed an increase of $91 \%$ (50.9 min) in cycling time to exhaustion using the same dosing regimen, combined with intense training in untrained subjects [122]. Although the statistical comparison was made between baseline measurement and post-treatment, and not additionally to the placebo measurements, it seems likely that this is a true effect as there was no change in the placebo treatment. Another study confirmed these findings in untrained females treated with $50 \mathrm{mg}$ prednisone daily for 1 week, which showed a $39 \%$ increase $(18.5 \mathrm{~min})$ in cycling time to exhaustion [123]. However, it should be noted that it is unclear how time to exhaustion relates to real-life endurance performance, which is usually not until exhaustion but until a finish line is reached. In summary, there is conflicting evidence on the effectiveness of glucocorticoids for improving different performance types. However, there seems to be an effect on specific strength tests and shuttle run time, and multiple, but not single, doses seem to improve time to exhaustion in moderately trained subjects. At the same time, only one study with 10 subjects showed an effect on a relevant performance surrogate marker, namely one-legged hopping maximal force.

\subsection{P1: Prohibited in Particular Sports}

This category covers substances prohibited in particular sports (i.e. archery, automobile, billiards, darts, golf, shooting, skiing/snowboarding and underwater sports) and contains only the group of $\beta$-blockers. This group of substances inhibits $\beta$-adrenergic receptors, thereby reducing heart rate, anxiety and tremulousness, which could potentially enhance performance in sports where precision and accuracy are vital. A double-blind, randomized, placebo-controlled, crossover study has been conducted evaluating the effect of metoprolol on shooting performance in amateur marksmen [124]. The study showed that, on average, participants improved their shooting when taking metoprolol compared with placebo, which was especially the case in the more skilled marksmen. It therefore seems that $\beta$-blockers do improve shooting performance, and possibly other precision and accuracy sports also included in this category, based on one study of 33 subjects.

\section{Conclusion}

Of all 23 specific substance classes defined in the 2018 Prohibited List, only five classes show evidence of having the ability to enhance actual sports performance (see Table 1). Anabolic agents can increase muscle strength at supratherapeutic doses; $\beta 2$-agonists can increase muscle strength and peak sprint power at high concentrations; some stimulants increase muscle strength, peak sprint power and decrease $1500 \mathrm{~m}$ run time; glucocorticoids can improve muscle strength; and $\beta$-blockers can improve accuracy. In addition, for another class there is evidence of performance enhancement, but only in untrained subjects: GH can improve sprint performance. Importantly, there is no robust evidence that any of the substance classes on the Prohibited List have the ability to improve endurance performance. Glucocorticoids improve time to exhaustion, but it is unclear whether this relates to actual endurance performance. Erythropoietin receptor agonists improve $V \mathrm{O}_{2 \max }$ and $P_{\max }$, but the available evidence shows no effect on actual endurance performance. What also becomes clear from this overview is that for most substance classes (11 of 23), there are no well-designed 
Table 1 Overview of all substance classes and evidence for performance enhancement

\begin{tabular}{|c|c|c|c|c|}
\hline Substance class & $\begin{array}{l}\text { Well- } \\
\text { designed } \\
\text { studies? }\end{array}$ & $\begin{array}{l}\text { Studies with } \\
\text { trained ath- } \\
\text { letes? }\end{array}$ & $\begin{array}{l}\text { Relevant performance parameters } \\
\text { showing improvement }\end{array}$ & $\begin{array}{l}\text { No. of trained athletes in stud- } \\
\text { ies with relevant performance } \\
\text { parameters }\end{array}$ \\
\hline S0: Non-approved substances & No & NA & NA & NA \\
\hline S1: Anabolic agents & Yes & Yes & $\begin{array}{l}\text { Muscle strength when combined with } \\
\text { strength training } \\
+10-20 \% \text { bench-press and squatting } \\
\text { power [24] } \\
+12 \% \text { bench press power [25] } \\
+23 \% \text { and }+12 \% \text { elbow flexion and } \\
\text { knee extension [26] }\end{array}$ & $\begin{array}{l}\text { Total: } 91 \\
40[24] \\
21[25] \\
30[26]\end{array}$ \\
\hline \multicolumn{5}{|c|}{ S2: Peptide hormones, growth factors, related substances and mimetics } \\
\hline Erythropoietin-receptor agonists & Yes & Yes & $\begin{array}{l}\text { No evidence for effects on relevant } \\
\text { endurance parameters, only on } \\
V \mathrm{O}_{2 \max } \text {, maximal power output and } \\
\text { time to exhaustion }\end{array}$ & $\begin{array}{l}\text { Total: } 161 \\
20[32] \\
11[34] \\
27[35] \\
16[36] \\
40[37] \\
47[39]\end{array}$ \\
\hline $\begin{array}{l}\text { Hypoxia-inducible factor activating } \\
\text { agents }\end{array}$ & No & NA & NA & NA \\
\hline GATA inhibitors & No & NA & NA & NA \\
\hline TGF $\beta$ inhibitors & No & NA & NA & NA \\
\hline Innate repair receptor agonists & No & NA & NA & NA \\
\hline $\begin{array}{l}\text { Chorionic gonadotrophin and lutein- } \\
\text { izing hormones and their releasing } \\
\text { factors }\end{array}$ & No & NA & NA & NA \\
\hline $\begin{array}{l}\text { Corticotrophins and their releasing } \\
\text { factors }\end{array}$ & Yes & Yes & No & $\begin{array}{l}\text { Total: } 24 \\
16[54] \\
8[55]\end{array}$ \\
\hline $\begin{array}{l}\text { Growth hormone, its fragments and } \\
\text { releasing factors }\end{array}$ & Yes & No & $\begin{array}{l}\text { Sprint performance } \\
+3.9 \% \text { Wingate sprint capacity [62] } \\
\text { in untrained subjects }\end{array}$ & $\begin{array}{l}\text { Total: } 123 \\
22[59] \\
30[60] \\
7[61] \\
64 \text { untrained [62] }\end{array}$ \\
\hline $\begin{array}{l}\text { Growth factors and growth factor } \\
\text { modulators }\end{array}$ & Yes & No & NA & NA \\
\hline S3: $\beta 2$-Agonists & Yes & Yes & $\begin{array}{l}\text { Peak sprint power, muscle strength } \\
+6 \% \text { maximal voluntary isometric } \\
\text { contraction, }+11 \% \text { peak twitch force } \\
\text { [70] } \\
+8.4 \% \text { quadriceps muscle strength, } \\
+2.2 \% \text { and }+3.3 \% \text { Wingate peak } \\
\text { and mean power, }+3 \% \text { Wingate total } \\
\text { work [71] } \\
+4 \% \text { (single dose) and }+6 \% \text { (multiple } \\
\text { dose) Wingate peak power }[72]\end{array}$ & $\begin{array}{l}\text { Total: } 39 \\
10[70] \\
9[71] \\
20[72]\end{array}$ \\
\hline \multicolumn{5}{|l|}{ S4: Hormone and metabolic modulators } \\
\hline Aromatase inhibitors & No & NA & NA & NA \\
\hline $\begin{array}{l}\text { Selective estrogen receptor modula- } \\
\text { tors }\end{array}$ & No & NA & NA & NA \\
\hline Other anti-estrogenic substances & No & NA & NA & NA \\
\hline $\begin{array}{l}\text { Agents modifying myostatin } \\
\text { function(s) }\end{array}$ & No & NA & NA & NA \\
\hline Metabolic modulators & No & NA & NA & NA \\
\hline S5: Diuretics and masking agents & Yes & Yes & No & $\begin{array}{l}\text { Total: } 70 \\
62[89] \\
8[90]\end{array}$ \\
\hline
\end{tabular}


Table 1 (continued)

\begin{tabular}{|c|c|c|c|c|}
\hline Substance class & $\begin{array}{l}\text { Well- } \\
\text { designed } \\
\text { studies? }\end{array}$ & $\begin{array}{l}\text { Studies with } \\
\text { trained ath- } \\
\text { letes? }\end{array}$ & $\begin{array}{l}\text { Relevant performance parameters } \\
\text { showing improvement }\end{array}$ & $\begin{array}{l}\text { No. of trained athletes in stud- } \\
\text { ies with relevant performance } \\
\text { parameters }\end{array}$ \\
\hline S6: Stimulants & Yes & Yes & $\begin{array}{l}\text { Muscle strength, sprint performance, } \\
1500 \text { m run time } \\
+9 \% \text { knee extension strength, }+3 \% \\
\text { peak Wingate sprint performance } \\
{[101]} \\
2 \% \text { decrease } 1500 \text { m run time }[104]\end{array}$ & $\begin{array}{l}\text { Total: } 58 \\
9[97] \\
22[101] \\
9[102] \\
11[103] \\
7[104]\end{array}$ \\
\hline S7: Narcotics & Yes & Yes & No & $\begin{array}{l}\text { Total: } 8 \\
8[105]\end{array}$ \\
\hline S8: Cannabinoids & Yes & No & NA & NA \\
\hline S9: Glucocorticoids & Yes & Yes & $\begin{array}{l}\text { One-legged hopping force } \\
+11 \% \text { one-legged hopping maximal } \\
\text { force }[118]\end{array}$ & $\begin{array}{l}\text { Total: } 10 \\
10[118]\end{array}$ \\
\hline $\begin{array}{l}\mathrm{P} 1: \beta \text {-Blockers (prohibited in particu- } \\
\text { lar sports) }\end{array}$ & Yes & Yes & $\begin{array}{l}\text { Shooting performance } \\
+13.4 \% \text { shooting performance }[124]\end{array}$ & $\begin{array}{l}\text { Total: } 33 \\
33[124]\end{array}$ \\
\hline
\end{tabular}

$N A$ not applicable, $T G F$ transforming growth factor, $\mathrm{VO}_{2} \max$ maximal oxygen consumption

studies evaluating the effects on performance (in trained subjects), meaning there is an absence of level 1 evidence. Physicians involved in administering such substances in particular are performing practices similar to off-license prescribing, and prescribing without evidence is considered bad medical practice. In contrast, for another six substance classes, well-designed studies are available that show some evidence of absence of (relevant) effects on performance. Overall, this review therefore shows that for the majority of substance classes ( 17 of 23 ), there is no convincing evidence that they enhance the performance of athletes. Moreover, in regard to the other five classes that are prohibited in all sports that do have evidence-based effects, it is unproven whether such effects are relevant or useful in many types of sport (e.g. endurance sports) as they only improve specific performance tasks (mainly strength and sprint power). Although these aspects do play some role in many sport disciplines (such as, for example, athletics or soccer), it is not very clear whether these effects would also impact actual performance in those disciplines. In any case, there are no studies investigating this, as we have shown. These findings together seem discordant with the general perception that substances on the Prohibited List, by definition, improve performance (to a great extent). This is especially evident when it is considered that a total of only 266 subjects (from 11 studies) form the clinical pharmacological level 1 evidence base for performance enhancement, the main reason for anti-doping efforts. Although the WADA Code only requires evidence for the potential to enhance performance, and there are two other criteria that can be applied to make a substance prohibited, we conclude there is a lack of high-level evidence for improvement of actual performance based on this review. Undertaking more high-quality clinical research to provide the level 1 evidence base for the current Prohibited List could fill some of these gaps. Some of this research could be impossible due to practical or ethical objections, but the current level of randomized evidence is low and there appear to be many areas where such research is possible. Furthermore, if there is clear evidence that there are no performance-enhancing effects of a certain class, athletes should be informed of this. This could potentially lead to fewer athletes being tempted to use these substances. Finally, such steps would lead to a more transparent and high-level evidence-based fight against doping, and possibly reduce the efforts and resources needed to test for abuse.

\section{Compliance with Ethical Standards}

Funding No sources of funding were used to assist in the preparation of this article.

Conflict of interest Jules Heuberger and Adam Cohen declare that they have no conflicts of interest relevant to the content of this review.

Open Access This article is distributed under the terms of the Creative Commons Attribution 4.0 International License (http://creativeco mmons.org/licenses/by/4.0/), which permits unrestricted use, distribution, and reproduction in any medium, provided you give appropriate credit to the original author(s) and the source, provide a link to the Creative Commons license, and indicate if changes were made.

\section{References}

1. The World Anti-Doping Agency. World anti-doping code 2015. https://www.wada-ama.org/sites/default/files/prohibited _list_2018_en.pdf. Accessed 24 May 2017. 
2. The World Anti-Doping Agency. Standard prohibited list 2018. Montreal: World Anti-Doping Agency; 2018.

3. de Hon O. The redundancy of the concept of 'spirit of sport' in discussions on the prohibited list of doping substances. Int $\mathbf{J}$ Sport Policy Polit. 2017;9(4):667-76.

4. Momaya A, Fawal M, Estes R. Performance-enhancing substances in sports: a review of the literature. Sports Med. 2015;45(4):517-31.

5. Bird SR, Goebel C, Burke LM, Greaves RF. Doping in sport and exercise: anabolic, ergogenic, health and clinical issues. Ann Clin Biochem. 2016;53(2):196-221.

6. Clarkson PM, Thompson HS. Drugs and sport. Research findings and limitations. Sports Med. 1997;24(6):366-84.

7. Birzniece V. Doping in sport: effects, harm and misconceptions. Intern Med J. 2015;45(3):239-48.

8. Burns PB, Rohrich RJ, Chung KC. The levels of evidence and their role in evidence-based medicine. Plast Reconstr Surg. 2011;128(1):305-10.

9. US FDA. FDA facts: biomarkers and surrogate endpoints. US FDA; 2017 [cited 30 Jul 2018]. https://www.fda.gov/aboutfda/ innovation/ucm512503.htm.

10. Pollock ML. Submaximal and maximal working capacity of elite distance runners. Part I: cardiorespiratory aspects. Ann N Y Acad Sci. 1977;301(1):310-22.

11. Joyner MJ, Coyle EF. Endurance exercise performance: the physiology of champions. J Physiol. 2008;586(1):35-44.

12. Sjödin B, Svedenhag J. Applied physiology of marathon running. Sports Med. 1985;2:83-99.

13. Lucia A, Hoyos J, Santalla A, Rez MP, Chicharro JL. Kinetics of $V_{2}$ in professional cyclists. Med Sci Sport Exerc. 2002;34(2):320-5

14. Jones AM. The physiology of the world record holder for the women's marathon. Int J Sports Sci Coach. 2006;1(2):101-16.

15. Coyle EF. Improved muscular efficiency displayed as Tour de France champion matures. J Appl Physiol. 2005;98(6):2191-6.

16. Jones AM. A five year physiological case study of an Olympic runner. Br J Sports Med. 1998;32(1):39-43.

17. Noakes T. Testing for maximum oxygen consumption has produced a brainless model of human exercise performance. $\mathrm{Br} \mathrm{J}$ Sports Med. 2008;42(7):551-5.

18. Jeukendrup A, Saris WH, Brouns F, Kester AD. A new validated endurance performance test. Med Sci Sports Exerc. 1996;28:266-70.

19. Laursen PB, Francis GT, Abbiss CR, Newton MJ, Nosaka K. Reliability of time-to-exhaustion versus time-trial running tests in runners. Med Sci Sports Exerc. 2007;39(8):1374-9.

20. Laursen PB, Rhodes EC, Langill RH, McKenzie DC, Taunton JE. Relationship of exercise test variables to cycling performance in an ironman triathlon. Eur J Appl Physiol. 2002;87(4-5):433-40.

21. van Someren K, Palmer GS. Prediction of 200-m sprint kayaking performance. Can J Appl Physiol. 2003;28:505-17.

22. Riechman SE, Zoeller RF, Balasekaran G, Goss FL, Robertson RJ. Prediction of $2000 \mathrm{~m}$ indoor rowing performance using a $30 \mathrm{~s}$ sprint and maximal oxygen uptake. J Sports Sci. 2002;20(9):681-7.

23. Hartgens F, Kuipers H. Effects of androgenic-anabolic steroids in athletes. Sports Med. 2004;34(8):513-54.

24. Bhasin S, Storer TW, Berman N, Callegari C, Clevenger B, Phillips J, et al. The effects of supraphysiologic doses of testosterone on muscle size and strength in normal men. N Engl J Med. 1996;335(1):1-7.

25. Giorgi A, Weatherby RP, Murphy PW. Muscular strength, body composition and health responses to the use of testosterone enanthate: a double blind study. J Sci Med Sport. 1999;2(4):341-55.
26. Friedl K, Dettori J, Hannan CJ Jr. Comparison of the effects of high dose testosterone and 19-nortestosterone to a replacement dose of testosterone on strength and body composition in normal men. J Steroid Biochem Mol Biol. 1991;40(4):607-12.

27. Stromme SB, Meen HD, Aakvaag A. Effects of an androgenic-anabolic steroid on strength development and plasma testosterone levels in normal males. Med Sci Sports Exerc. 1974;6(3):203-7.

28. Hervey GR, Hutchinson I, Knibbs AV, Burkinshaw L, Jones PRM, Norgan NG, et al. "Anabolic" effects of methandienone in men undergoing athletic training. Lancet. 1976;308(7988):699-702.

29. Baume N, Schumacher YO, Sottas PE, Bagutti C, Cauderay $\mathrm{M}$, Mangin P, et al. Effect of multiple oral doses of androgenic anabolic steroids on endurance performance and serum indices of physical stress in healthy male subjects. Eur J Appl Physiol. 2006;98(4):329-40.

30. Lundby C, Millet GP, Calbet JA, Bärtsch P, Subudhi AW. Does 'altitude training' increase exercise performance in elite athletes? Br J Sports Med. 2012;46(11):792-5.

31. Heuberger JAAC, Cohen Tervaert JM, Schepers FML, Vliegenthart ADB, Rotmans JI, Daniels JMA, et al. Erythropoietin doping in cycling: Lack of evidence for efficacy and a negative risk-benefit. Br J Clin Pharmacol. 2013;75(6):1406-21.

32. Birkeland K, Stray-Gundersen J, Hemmersbach P, Hallén J, Haug E, Bahr R. Effect of rhEPO administration on serum levels of sTfR and cycling performance. Med Sci Sport Exerc. 2000;32:1238-43.

33. Wilkerson DP, Rittweger J, Berger NJ, Naish PF, Jones AM. Influence of recombinant human erythropoietin treatment on pulmonary $\mathrm{O}_{2}$ uptake kinetics during exercise in humans. J Physiol. 2005;568(2):639-52.

34. Ninot G, Connes P, Caillaud C. Effects of recombinant human erythropoietin injections on physical self in endurance athletes. J Sports Sci. 2006;24:383-91.

35. Parisotto R, Gore CJ, Emslie KR, Ashenden MJ, Brugnara $\mathrm{C}$, Howe $\mathrm{C}$, et al. A novel method utilising markers of altered erythropoiesis for the detection of recombinant human erythropoietin abuse in athletes. Haematologica. 2000;85(6):564-72.

36. Connes P, Perrey S, Varray A, Préfaut C, Caillaud C. Faster oxygen uptake kinetics at the onset of submaximal cycling exercise following 4 weeks recombinant human erythropoietin (r-HuEPO) treatment. Pflügers Arch. 2003;447(2):231-8.

37. Annaheim S, Jacob M, Krafft A, Breymann C, Rehm M, Boutellier U. RhEPO improves time to exhaustion by nonhematopoietic factors in humans. Eur J Appl Physiol. 2016;116(3):623-33.

38. Clark B, Woolford SM, Eastwood A, Sharpe K, Barnes PG, Gore CJ. Temporal changes in physiology and haematology in response to high- and micro-doses of recombinant human erythropoietin. Drug Test Anal. 2017;9(10):1561-71.

39. Heuberger JAAC, Rotmans JI, Gal P, Stuurman FE, Van Westende J, Post TE, et al. Effects of erythropoietin on cycling performance of well trained cyclists: a double-blind, randomised, placebo-controlled trial. Lancet Haematol. 2017;4(8):e374-86.

40. Bowie E, Hurley P. Cobalt chloride in the treatment of refractory anaemia in patients undergoing long-term haemodialysis. Aust N Z J Med. 1975;5(4):306-13.

41. Edwards MS, Curtis JR. Use of cobaltous chloride in anæmia of maintenance-hæmodialysis patients. Lancet. 1971;298(7724):582-3.

42. Ebert B, Jelkmann W. Intolerability of cobalt salt as erythropoietic agent. Drug Test Anal. 2014;6(3):185-9.

43. Stoppe C, Ney J, Brenke M, Goetzenich A, Emontzpohl C, Schälte G, et al. Sub-anesthetic xenon increases erythropoietin 
levels in humans: a randomized controlled trial. Sports Med. 2016;46(11):1753-66.

44. Balachandran A, Streiner DL, Signorile JF. Comment on "Subanesthetic xenon increases erythropoietin levels in humans: a randomized controlled trial". Sports Med. 2017;47(2):379.

45. Gupta N, Wish JB. Hypoxia-inducible factor prolyl hydroxylase inhibitors: a potential new treatment for anemia in patients with CKD. Am J Kidney Dis. 2017;69(6):815-26.

46. Locatelli F, Fishbane S, Block GA, Macdougall IC. Targeting hypoxia-inducible factors for the treatment of anemia in chronic kidney disease patients. Am J Nephrol. 2017;45(3):187-99.

47. Macdougall IC. New anemia therapies: translating novel strategies from bench to bedside. Am J Kidney Dis. 2012;59(3):444-51.

48. Imagawa S, Matsumoto K, Horie M, Ohkoshi N, Nagasawa T, Doi T, et al. Does K-11706 enhance performance and why? Int J Sport Med. 2007;28(11):928-33.

49. Komrokji R, Garcia-Manero G, Ades L, Prebet T, Steensma DP, Jurcic JG, et al. Sotatercept with long-term extension for the treatment of anaemia in patients with lower-risk myelodysplastic syndromes: a phase 2, dose-ranging trial. Lancet Haematol. 2018;5(2):e63-72.

50. Platzbecker U, Germing U, Götze KS, Kiewe P, Mayer K, Chromik J, et al. Luspatercept for the treatment of anaemia in patients with lower-risk myelodysplastic syndromes (PACE-MDS): a multicentre, open-label phase 2 dose-finding study with longterm extension study. Lancet Oncol. 2017;18(10):1338-47.

51. Boesch S, Nachbauer W, Mariotti C, Sacca F, Filla A, Klockgether T, et al. Safety and tolerability of carbamylated erythropoietin in Friedreich's ataxia. Mov Disord. 2014;29(7):935-9.

52. Handelsman DJ. The rationale for banning human chorionic gonadotropin and estrogen blockers in sport. J Clin Endocrinol Metab. 2006;91(5):1646-53.

53. Padrón RS, Wischusen J, Hudson B, Burger HG, Kretser DMD. Prolonged biphasic response of plasma testosterone to single intramuscular injections of human chorionic gonadotropin. $\mathbf{J}$ Clin Endocrinol Metab. 1980;50(6):1100-4.

54. Soetens E, De Meirleir K, Hueting JE. No influence of ACTH on maximal performance. Psychopharmacology (Berl). 1995;118:260-6.

55. Baume N, Steel G, Edwards T, Thorstensen E, Miller BF. No variation of physical performance and perceived exertion after adrenal gland stimulation by synthetic ACTH $\left(\right.$ Synacthen ${ }^{\circledR}$ ) in cyclists. Eur J Appl Physiol. 2008;104(4):589-600.

56. Woodhouse LJ, Mukherjee A, Shalet SM, Ezzat S. The influence of growth hormone status on physical impairments, functional limitations, and health-related quality of life in adults. Endocr Rev. 2006;27(3):287-317.

57. Liu H, Bravata DM, Olkin I, Friedlander A, Liu V, Roberts B, et al. Review systematic review : the effects of growth hormone on athletic performance. Ann Intern Med. 2008;148(10):747-58.

58. Yarasheski KE, Campbell JA, Smith K, Rennie MJ, Holloszy JO, Bier DM. Effect of growth hormone and resistance exercise on muscle growth in young men. Am J Physiol Metab. 1992;262(3):E261-7.

59. Deyssig R, Frisch H, Blum W, Waldhor T. Effect of growth hormone treatment on hormonal parameters, body composition and strength in athletes. Acta Endocrinol (Copenh). 1993;128(4):313-8.

60. Berggren A, Ehrnborg C, Rosén T, Ellegård L, Bengtsson BÅ, Caidahl K. Short-term administration of supraphysiological recombinant human growth hormone $(\mathrm{GH})$ does not increase maximum endurance exercise capacity in healthy, active young men and women with normal GH-insulin-like growth factor I axes. J Clin Endocrinol Metab. 2005;90(6):3268-73.
61. Lange KHW, Larsson B, Flyvbjerg A, Dall R, Bennekou M, Rasmussen $\mathrm{MH}$, et al. Acute growth hormone administration causes exaggerated increases in plasma lactate and glycerol during moderate to high intensity bicycling in trained young men. $\mathrm{J}$ Clin Endocrinol Metab. 2002;87(11):4966-75.

62. Meinhardt U, Nelson AE, Hansen JL, Birzniece V, Clifford D, Leung $\mathrm{K}$. The effects of growth hormone on body composition and physical performance in recreational athletes. Ann Intern Med. 2010;152:568-77.

63. Creaney L, Hamilton B. Growth factor delivery methods in the management of sports injuries: the state of play. Br J Sports Med. 2008;42(5):314-20.

64. Morishita R, Makino H, Aoki M, Hashiya N, Yamasaki K, Azuma $\mathrm{J}$, et al. Phase I/IIa clinical trial of therapeutic angiogenesis using hepatocyte growth factor gene transfer to treat critical limb ischemia. Arterioscler Thromb Vasc Biol. 2011;31(3):713-20.

65. Steed DL. Clinical evaluation of recombinant human plateletderived growth factor for the treatment of lower extremity diabetic ulcers. J Vasc Surg. 2018;21(1):71-81.

66. Ruff D, Crockford D, Girardi G, Zhang Y. A randomized, placebo-controlled, single and multiple dose study of intravenous thymosin $\beta 4$ in healthy volunteers. Ann N Y Acad Sci. 2010;1194(1):223-9.

67. Guha N, Nevitt SP, Francis M, Woodland JA, Böhning D, Sönksen $\mathrm{PH}$, et al. The effects of recombinant human insulin-like growth factor-I/insulin-like growth factor binding protein-3 administration on body bomposition and physical fitness in recreational athletes. J Clin Endocrinol Metab. 2015;100(8):3126-31.

68. Pluim BM, de Hon O, Staal JB, Limpens J, Kuipers H, Overbeek $\mathrm{SE}$, et al. $\beta_{2}$-Agonists and physical performance: a systematic review and meta-analysis of randomized controlled trials. Sports Med. 2011;41(1):39-57.

69. Cairns SP, Borrani F. $\beta$-Adrenergic modulation of skeletal muscle contraction: key role of excitation-contraction coupling. J Physiol. 2015;593(21):4713-27.

70. Hostrup M, Kalsen A, Ørtenblad N, Juel C, Mørch K, Rzeppa S, et al. $\beta 2$-Adrenergic stimulation enhances $\mathrm{Ca}^{2+}$ release and contractile properties of skeletal muscles, and counteracts exerciseinduced reductions in $\mathrm{Na}^{+}-\mathrm{K}^{+}-$ATPase $V_{\max }$ in trained men. $\mathrm{J}$ Physiol. 2014;592(24):5445-59.

71. Hostrup M, Kalsen A, Bangsbo J, Hemmersbach P, Karlsson $\mathrm{S}$, Backer V. High-dose inhaled terbutaline increases muscle strength and enhances maximal sprint performance in trained men. Eur J Appl Physiol. 2014;114(12):2499-508.

72. Hostrup M, Kalsen A, Auchenberg M, Bangsbo J, Backer V. Effects of acute and 2-week administration of oral salbutamol on exercise performance and muscle strength in athletes. Scand J Med Sci Sports. 2016;26(1):8-16.

73. Decorte N, Bachasson D, Guinot M, Flore P, Levy P, Verges S, et al. Impact of salbutamol on neuromuscular function in endurance athletes. Med Sci Sports Exerc. 2013;45(March):1925-32.

74. Mauras N, Lima J, Patel D, Rini A, di Salle E, Kwok A, et al. Pharmacokinetics and dose finding of a potent aromatase inhibitor, aromasin (exemestane), in young males. J Clin Endocrinol Metab. 2003;88(12):5951-6.

75. Duschek EJ, Gooren L, Netelenbos J. Effects of raloxifene on gonadotrophins, sex hormones, bone turnover and lipids in healthy elderly men. Eur J Endocrinol. 2004;150:539-46.

76. Guay AT, Bansal S, Heatley GJ. Effect of raising endogenous testosterone levels in impotent men with secondary hypogonadism: double blind placebo-controlled trial with clomiphene citrate. J Clin Endocrinol Metab. 1995;80(12):3546-52.

77. Tenover J, Dahl K, Hseuh A, Lim P, Matsumoto ABW. Serum bioactive and immunoreactive follicle-stimulating hormone levels and the response to clomiphene in healthy young and elderly men. J Clin Endocrinol Metab. 1987;64(6):1103-8. 
78. Fedoruk MN, Rupert JL. Myostatin inhibition: a potential performance enhancement strategy? Scand J Med Sci Sports. 2008;18(2):123-31.

79. Saitoh M, Ishida J, Ebner N, Anker SD, von Haehling S. Myostatin inhibitors as pharmacological treatment for muscle wasting and muscular dystrophy. JCSM Clin Rep. 2017;2(1):e37:1-10.

80. Narkar VA, Downes M, Yu RT, Embler E, Wang Y-X, Banayo E, et al. AMPK and PPAR $\delta$ agonists are exercise mimetics. Cell. 2008;134(3):405-15.

81. Tan CK, Zhuang Y, Wahli W. Synthetic and natural peroxisome proliferator-activated receptor (PPAR) agonists as candidates for the therapy of the metabolic syndrome. Expert Opin Ther Targets. 2017;21(3):333-48.

82. Niederberger E, King TS, Russe O, Geisslinger G. Activation of AMPK and its impact on exercise capacity. Sports Med. 2015;45(11):1497-509.

83. Braun B, Eze P, Stephens BR, Hagobian TA, Sharoff CG, Chipkin SR, et al. Impact of metformin on peak aerobic capacity. Appl Physiol Nutr Metab. 2008;33(1):61-7.

84. Johnson ST, Robert C, Bell GJ, Bell RZ, Lewanczuk RZ, Boulé NG. Acute effect of metformin on exercise capacity in active males. Diabetes Obes Metab. 2008;10(9):747-54.

85. Kuipers H, Ruijsch Van Dugteren G. Letter to the editorsThe prohibited list and cheating in sport. Int J Sports Med. 2006;27(1):80-2.

86. Greenblatt HK, Greenblatt DJ. Meldonium (Mildronate): a performance-enhancing drug? Clin Pharmacol Drug Dev. 2016;5(3):167-9.

87. Vitale C, Marazzi G, Pelliccia F, Volterrani M, Cerquetani E, Spoletini I, et al. Trimetazidine improves exercise performance in patients with peripheral arterial disease. Pharmacol Res. 2011;63(4):278-83.

88. Cadwallader AB, de la Torre $\mathrm{X}$, Tieri A, Botrè F. The abuse of diuretics as performance-enhancing drugs and masking agents in sport doping: pharmacology, toxicology and analysis. Br $\mathbf{J}$ Pharmacol. 2010;161(1):1-16.

89. Caldwell JE, Ahonen E, Nousiainen U. Differential effects of sauna-, diuretic-, and exercise-induced hypohydration. J Appl Physiol. 1984;57(4):1018-23.

90. Armstrong LE, Costill DL, Fink WJ. Influence of diureticinduced dehydration on competitive running performance. Med Sci Sports Exerc. 1985;17(4):456-61.

91. Kowalchuk JM, Heigenhauser GJ, Sutton JR, Jones NL. Effect of acetazolamide on gas exchange and acid-base control after maximal exercise. J Appl Physiol. 1992;72(1):278-87.

92. Stager JM, Tucker A, Cordain L, Engebretsen BJ, Brechue WF, Matulich CC. Normoxic and acute hypoxic exercise tolerance in man following acetazolamide. Med Sci Sports Exerc. 1990;22(2):178-84.

93. Schoene RB, Bates PW, Larson EB, Pierson DJ. Effect of acetazolamide on normoxic and hypoxic exercise in humans at sea level. J Appl Physiol Respir Env Exerc Physiol. 1983;55(6):1772-6.

94. Fulco CS, Muza SR, Ditzler D, Lammi E, Lewis SF, Cymerman A. Effect of acetazolamide on leg endurance exercise at sea level and simulated altitude. Clin Sci. 2006;110(6):683-92.

95. Chandler JV, Blair SN. The effect of amphetamines on selected physiological components related to athletic success. Med Sci Sports Exerc. 1980;12(1):65-9.

96. Swart J, Lamberts RP, Lambert MI, St Clair Gibson A, Lambert EV, Skowno J, et al. Exercising with reserve: evidence that the central nervous system regulates prolonged exercise performance. Br J Sports Med. 2009;43(10):782-8.

97. Roelands B, Hasegawa H, Watson P, Piacentini MF, Buyse L, De Schutter G, et al. The effects of acute dopamine reuptake inhibition on performance. Med Sci Sports Exerc. 2008;40:879-85.

98. Dufka F, Galloway G, Baggott M, Mendelson J. The effects of inhaled L-methamphetamine on athletic performance while riding a stationary bike: a randomised placebo-controlled trial. Br J Sports Med. 2009;43(11):832-5.

99. Bell DG, Jacobs IRA, Ellerington K. Effect of caffeine and ephedrine ingestion on anaerobic exercise performance. Med Sci Sports Exerc. 2001;33(8):1399-403.

100. Jacobs I, Pasternak H, Bell DG. Effects of ephedrine, caffeine, and their combination on muscular endurance. Med Sci Sports Exerc. 2003;35(6):987-94.

101. Gill ND, Shield A, Blazevich AJ, Zhou S, Weatherby RP. Muscular and cardiorespiratory effects of pseudoephedrine in human athletes. Br J Clin Pharmacol. 2000;50(3):205-13.

102. Chester N, Reilly T, Mottram D. Physiological, subjective and performance effects of pseudoephedrine and phenylpropanolamine during endurance running exercise. Int J Sports Med. 2003;24:3-8.

103. Hodges ANH, Lynn BM, Bula JE, Donaldson MG, Dagenais MO, McKenzie DC. Effects of pseudoephedrine on maximal cycling power and submaximal cycling efficiency. Med Sci Sport Exerc. 2003;35(8):1316-9.

104. Hodges K, Hancock S, Currell K, Hamilton B, Jeukendrup AE. Pseudoephedrine enhances performance in $1500 \mathrm{~m}$ runners. Med Sci Sport Exerc. 2006;38(2):329-34.

105. Amann M, Proctor LT, Sebranek JJ, Pegelow DF, Dempsey JA. Opioid-mediated muscle afferents inhibit central motor drive and limit peripheral muscle fatigue development in humans. J Physiol. 2009;587(1):271-83.

106. Holgado D, Hopker J, Sanabria D, Zabala M. Analgesics and sport performance: beyond the pain-modulating effects. PM R. 2018;10(1):72-82.

107. Huestis MA. Cannabis (Marijuana): effects on human behavior and performance. Forensic Sci Rev. 2002;14(1-2):15-60.

108. Hilderbrand RL. High-performance sport, marijuana, and cannabimimetics. J Anal Toxicol. 2011;35(9):624-37.

109. Huestis MA, Mazzoni I, Rabin O. Cannabis in sport: anti-doping perspective. Sports Med. 2011;41(11):949-66.

110. Trinh KV, Diep D, Robson H. Marijuana and its effects on athletic performance: a systematic review. Clin J Sport Med. 2018;28(4):350-7.

111. Kennedy MC. Cannabis: exercise performance and sport. A systematic review. J Sci Med Sport. 2017;20(9):825-9.

112. Steadward RD, Singh M. The effects of smoking marihuana on physical performance. Med Sci Sports. 1975;7(4):309-11.

113. Collomp K, Arlettaz A, Buisson C, Lecoq A-M, Mongongu C. Glucocorticoid administration in athletes: performance, metabolism and detection. Steroids. 2016;115:193-202.

114. Marquet P, Lac G, Chassain AP, Habrioux G, Gallen FX. Dexamethasone in resting and exercising men: I. Effects on bioenergetics, minerals, and related hormones. J Appl Physiol. 1999;87(1):175-82.

115. Kuipers H, Van't Hullenaar GAC, Pluim BM, Overbeek SE, De Hon O, Van Breda EJ, et al. Four weeks' corticosteroid inhalation does not augment maximal power output in endurance athletes. Br J Sports Med. 2008;42(11):568-71.

116. Nordsborg N, Ovesen J, Thomassen M, Zangenberg M, Jøns C, Iaia FM, et al. Effect of dexamethasone on skeletal muscle $\mathrm{Na}^{+}$ $\mathrm{K}^{+}$pump subunit specific expression and $\mathrm{K}^{+}$homeostasis during exercise in humans. J Physiol. 2008;586(5):1447-59.

117. Casuso RA, Melskens L, Bruhn T, Secher NH, Nordsborg NB. Glucocorticoids improve high-intensity exercise performance in humans. Eur J Appl Physiol. 2014;114(2):419-24. 
118. Zorgati H, Prieur F, Vergniaud T, Cottin F, Do MC, Labsy Z, et al. Ergogenic and metabolic effects of oral glucocorticoid intake during repeated bouts of high-intensity exercise. Steroids. 2014;86:10-5.

119. Arlettaz A, Collomp K, Portier H, Lecoq AM, Pelle A, De Ceaurriz J. Effects of acute prednisolone intake during intense submaximal exercise. Int J Sports Med. 2006;27(9):673-9.

120. Arlettaz A, Collomp K, Portier H, Lecoq AM, Rieth N, Le Panse $\mathrm{B}$, et al. Effects of acute prednisolone administration on exercise endurance and metabolism. Br J Sports Med. 2008;42(4):250-4.

121. Arlettaz A, Portier H, Lecoq AM, Rieth N, De Ceaurriz J, Collomp K. Effects of short-term prednisolone intake during submaximal exercise. Med Sci Sports Exerc. 2007;39(9):1672-8.
122. Collomp K, Arlettaz A, Portier H, Lecoq A-M, Le Panse B, Rieth $\mathrm{N}$, et al. Short-term glucocorticoid intake combined with intense training on performance and hormonal responses. Br J Sports Med. 2008;42(12):983-8.

123. Le Panse B, Thomasson R, Jollin L, Lecoq AM, Amiot V, Rieth $\mathrm{N}$, et al. Short-term glucocorticoid intake improves exercise endurance in healthy recreationally trained women. Eur J Appl Physiol. 2009;107(4):437-43.

124. Kruse P, Ladefoged J, Nielsen U, Paulev PE, Sørensen JP. Betablockade used in precision sports: effect on pistol shooting performance. J Appl Physiol. 1986;61:417-20. 